\title{
Students' participation in entrepreneurship skills acquisition programmes in Adamawa state polytechnic yola, Nigeria
}

\begin{abstract}
This study assessed students' participation in entrepreneurship skills acquisition programme in Adamawa State Polytechnic Yola, Nigeria. Primary data were collected by the use of questionnaire administered to randomly selected 80 respondents proportionate to the number of students from each Department. Data collected were analyzed using percentages, mean, frequency distribution and regression analysis. The findings revealed that majority $(67.5 \%)$ of the respondents were males, $61.34 \%$ of them were within age of $20-29$ years and only $15 \%$ were married having an average household size of 3 persons. Majority $(76 \%)$ of the respondents has their highest level of education as secondary with $78 \%$ been student as their main occupation. The result shows that $85 \%$ and $35 \%$ participated in computer and male saloon skills respectively. The regression analysis result revealed that the variables of age $\left(\mathrm{X}_{1}\right)$, marital status $\left(\mathrm{X}_{2}\right)$ and household size $\left(\mathrm{X}_{3}\right)$ to be significantly related with the number skills acquired. The coefficient of multiple determinations $\left(\mathrm{R}^{2}\right)$ was estimated at 0.8796 indicating that $87.96 \%$ of the variation in skills acquired is explained by the variables included in the model. The major problems encountered by the respondents inadequate of training facilities, inadequate of trainers and capital to start their business. Participation in entrepreneurship skills acquisition programme was found to have positive impact on the respondents. As those who were found to be engaged, learned various skills and some were gainfully employed through the skills they learned.The research recommends among others that adequate facilities/materials and trainers should be provided for each skill.
\end{abstract}

Keywords: students, entrepreneurship, participation, programmes
Volume 2 Issue 2 - 2018

\author{
Usman IS, Waziri UM, Abdullahi A, Babayo AA \\ Department of Agricultural Economics and Extension, Modibbo \\ Adama University Technology Yola, Nigeria
}

\author{
Correspondence: Usman IS, Department of Agricultural \\ Economics and Extension, Modibbo Adama University \\ Technology Yola, Nigeria, Tel +234 7067952643, \\ Email ibrogirei2@mautech.edu.ng
}

Received: February 10,2018| Published: April 17, 2018

\section{Introduction}

Youth is defined as a state or time of being young, a transition period between childhood and adulthood, characterized energy, intelligence and attributes that enable youth to improve their knowledge and capabilities. ${ }^{1}$ The United Nation Youth Agenda ${ }^{2}$ defined youth as individual between the ages of 15 to 25 years of age. In the Nigerian context, youths are those groups of individuals within the age bracket of 18 to 30 years. $^{3}$

Kauffman Foundation ${ }^{4}$ defined entrepreneurship training as the process of providing individuals with knowledge and skills to recognize opportunities that others have over-looked to have insight, self-esteem and knowledge to act where others have hesitated. It includes opportunity recognition marshaling resources in the face of risk and initiating a business venture. It can be seen as a programme design to train youth in vocational skills in various trades such as welding, automobile, electrical and electronic skills, tailoring, brick lying etc.

According to Madumere-Obike \& Abraham, ${ }^{5}$ entrepreneurship training enhances creativity in technical and vocational skills and inculcates in the individuals the abilities that are necessary for them to be self-reliant through technical education. One of the objectives of entrepreneurship training is to provide students with skills and motivations in order to enhance entrepreneurial endeavor in any enterprise of their choice. Etuk \& $\mathrm{Ekpo}^{6}$ affirmed that, entrepreneurship brings together the factors of production; human, land, labour and capital to make products for public development and consumption. It incorporates the willingness and ability of a person to explore and exploit investment opportunities, establish and manage successful business enterprise.

Participation refers to the process of sharing decision which affects one's life and the life of the community. Therefore, youths' participation describes the group of young people who consciously and creatively employ their knowledge, skills and resources to bring about development and positive change in their economic, social, physical, physiological and political wellbeing. Ultimately, technical/ entrepreneurship skills acquisition can support youths to have selfcontrol and self-dependent, avoidance of social vices and greater development to the community, state and nation as well.

Youths have being known to play important contributions to the development of many nations. It is believed that youths have played significant role toward the development of the first world countries. Nigeria is blessed with many active youths but yet these groups of young individuals are not given the opportunity to contribute their quota to the nation building due to scarcity of skill jobs. The National Bureau of Statistics ${ }^{7}$ reported that $58.1 \%$ of youths within the age bracket of 15-34 years are either unemployed or underemployed and even those that are employed are looking for better standard of living and their expectation are rising daily. Unemployment is defined as the proportion of labour force that was available for but did not work in a week preceding the survey period for at least 39 hours. The National Bureau of Statistic ${ }^{8}$ reported that, half of the Nigerian population is youths and majority of them are unemployed. 
Youths are major ingredients needed for the country (Nigeria) Therefore, the preparation for any nation for productive life depends on programmes and policies designed for these able people, and in such the country must find alternatives to the scarce white collar jobs that will meet the demand of the youths and will also add to the development of this country. One of these alternatives is the vocational skills.

The introduction of entrepreneurship development skills in 2011 for students pursuing certificate in diploma in various academic disciplines in Adamawa state Polytechnic Yola, have granted youths the opportunities to learn and acquire entrepreneurship skills. This will guarantee carrier opportunity and will also help youths to realize their potentials and reduce over dependent on white collar jobs and hence, will alleviate the level of unemployment in the state. Since the introduction of the programme in the institution, no empirical study was conducted to assess students' participation in the programme. Therefore, this research attempted to provide answers to the following research questions:

a. What are the socio-economic characteristics of the respondents?

b. What are the types of skills acquired by the respondents?

c. Are there relationship between the socio-economic characteristics and skill acquired by the respondents?

d. What are the problems faced by the respondents in effective participation in the entrepreneurship training?

\section{Objectives of the study}

The broad objective of the study is to assess youths' participation in entrepreneurship skills training in Adamawa State Polytechnic, Yola. The specific objectives of the study are to: Describe the socioeconomic characteristics of the respondents.Identify the skills acquired by the respondents.Ascertain the socio-economic characteristics and the skill acquired by the respondents.Identify the problems faced by the respondents.

\section{Methodology}

\section{The study area}

The study was conducted in Adamawa state polytechnic Yola, Yola-North Local Government Area of Adamawa State. The Local Government Area is bounded to the north, south, and west by Yola south Local Government Area and to the east by Girei Local Government Area respectively. It lies between latitude $9^{\circ} 16^{1} \mathrm{~N}$ to $9^{\circ} 20^{1} \mathrm{~N}$ of the equator and longitude $12^{\circ} 26^{1} \mathrm{E}$ to $12^{\circ} 30^{1} \mathrm{E}$ of the Greenwich meridian with an altitude of 185.9 meters above sea level (Figure 1). The study area is typically marked by wet and dry seasons. The wet season starts in April and end in October, while the dry season commences in November and ends in late March. The maximum temperature is around $41.8^{\circ} \mathrm{C}$ and the average minimum temperature is $15.2^{\circ} \mathrm{C}^{9}$ with an average annual rainfall of $180 \mathrm{~mm}$. The relative humidity between January and March is extremely lower (20$30 \%) .{ }^{9}$ It starts increasing as from April and reaches the peak about $(80 \%)$ in August as the wettest month. In the months of December to February, dry harmattan weather characterizes the area which is cold and dusty. Yola North Local Government Area with an approximate land area of 1913 square kilometers with a radius of $3.522 \mathrm{~km}$, has a population of 199,674 people. ${ }^{3}$ The major occupations of the people in the study area are civil service, business (trading) and farming as the occupation of the few. The predominant tribes in the local government are Fulani, Hausa, Laka among others. ${ }^{10}$

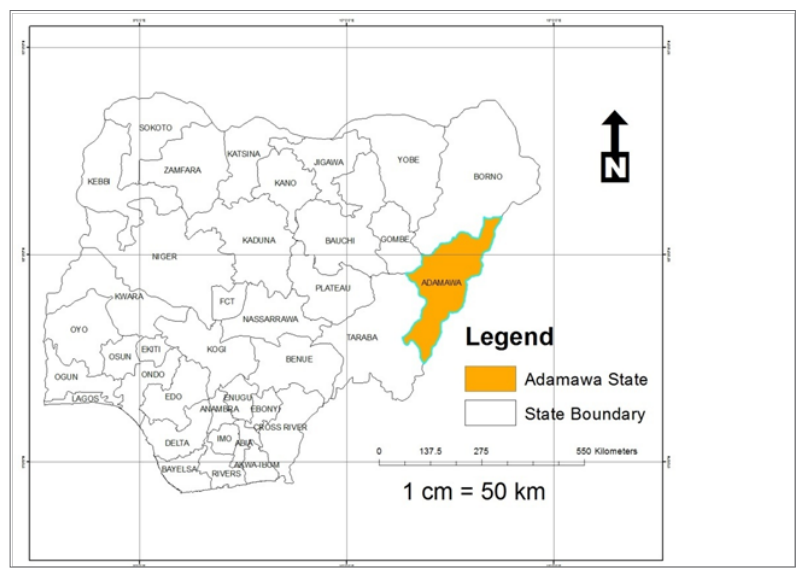

Figure I Map of Nigeria showing Adamawa State.

\section{Source of data and sampling technique}

Primary data were used and it was generated through the administration of semi structured questionnaires administered to the respondents. The list of 808 diploma students participating in the entrepreneurship training was obtained from the office of the Head of Departments and was used as sampling frame. From the list, a total of 80 respondents were randomly selected proportionate to the number of students from each Department who were served with questionnaires (Table 1).

Table I Sampling frame and Sampling Technique

\begin{tabular}{lll}
\hline Department & $\begin{array}{l}\text { Registered } \\
\text { students }\end{array}$ & $\begin{array}{l}\text { Students } \\
\text { selected }\end{array}$ \\
\hline Business education & 420 & 42 \\
Computer Science & 80 & 8 \\
$\begin{array}{l}\text { Science laboratory } \\
\text { Technology }\end{array}$ & 250 & 25 \\
Agricultural Engineering & 54 & 5 \\
Total & 804 & 80 \\
\hline
\end{tabular}

Source: Pre-Survey, 2017

\section{Analytical techniques}

The analytical tools used for this study were descriptive and inferential statistics. Descriptive statistics involved frequency distribution and percentage was used to analyze socio-economic characteristics respondents, skills acquired by the respondents and problems faced by the respondents (objectives i, ii, iv).While inferential Statistics (Multiple regression) was used to analyze relationship between the socio-economic of the respondents and skills acquired (objective iii). The formula is implicitly given as:

$\mathrm{Y}=\mathrm{f}\left(\mathrm{X}_{1}, \mathrm{X}_{2}, \mathrm{X}_{3,} \mathrm{X}_{4} \quad \mathrm{X}_{\mathrm{n}}+\mathrm{U}_{\mathrm{i}}\right)$. 
Where,

$\mathrm{Y}=$ Level of participation (Percentage number of skills acquired by the respondent).

$\mathrm{X}_{1}=$ Age of respondent (Years).

$\mathrm{X}_{2}=$ Marital status $(1=$ married, $0=$ single $)$.

$\mathrm{X}_{3}=$ Household sizeif any (Number).

$\mathrm{X}_{4}=$ Educational level (Number of years spent in School).

$\mathrm{X}_{5}=$ Occupation $(1=$ Student, $0=$ others $)$.

$\mathrm{F}=$ functional form.

$\mathrm{X}-\mathrm{Xn}$ are the values of independent variables to be use.

$\mathrm{Ui}=$ Error term (Stochastic error)

\section{Results and discussion}

\section{Socio-economic characteristics of the respondents}

Result on Table 2 gave details of socio-economic characteristics of the respondents. It shows that majority $(67.5 \%)$ of the respondents were male while $32.5 \%$ were female. This indicates that male dominated in entrepreneurship skill acquisition. The result is in line with study conducted by Albert et al. ${ }^{11}$ on analysis of entrepreneurship skill acquisition programmes on employment opportunities in rural areas of River State, Nigeria. Similarly, Table 2 shows that majority $(61.34 \%)$ of the respondents are within the range of 20-29 years of age. This indicated that majority of the sampled students fall within the younger age and they are still in their active learning age. The result is in cognisance to the findings conducted by Ajayi \& Yisa ${ }^{12}$ in Niger state on youth empowerment-scheme who reported that more than half of the participants were between 21-30 years. Table 2 also revealed that only $15 \%$ of the respondents were married with average house hold size of 3 people. This implies that most of the students are yet to marry. This will give them more time to concentrate on learning skills since have no responsibility on them. The research result also revealed that $76.25 \%$ of the respondents were Secondary School Certificate. The result contradict the findings of Pur et al. ${ }^{13}$ on the role of youth association in empowering youths agricultural activities in Adamawa State Nigeria, revealed that majority $(61.9 \%)$ of the respondents attained advanced level. About $77.5 \%$ of the respondents are mainly students without any other occupation.

Table 2 Socio-economic Characteristics of the Respondents $(n=80)$

\begin{tabular}{lll}
\hline Variable & Percentage (\%) & Mean \\
\hline Sex & & \\
Male & 67.5 & \\
Female & 32.5 & \\
Age & & \\
$\leq 19$ & 16.25 & \\
$20-29$ & 61.34 & \\
$30-39$ & 22.5 \\
Marital status & \\
Single & 85 \\
\hline
\end{tabular}

Table continued

\begin{tabular}{lll}
\hline Variable & Percentage (\%) & Mean \\
\hline Married & 15 & \\
House hold size & \\
I & 93.75 & \\
2 & 5 & 2 \\
3 & 1.25 & \\
Education level & \\
Secondary & 76.25 & \\
Tertiary & 23.75 \\
Occupation & \\
Students & 77.5 \\
Civil Servant & 22.5 \\
\hline
\end{tabular}

Source: Field Survey, 2017

\section{Skills acquired by the respondents}

Result in Table 3 revealed that most $(85.0 \%)$ of the respondents learned computer skills, this may be as a result of technological age that we are in that is why most of them are interested in computer skill. Thirty five $(35.0 \%)$ of the respondents went for male saloon skills followed by $32.5 \%$ who acquired the skill of how to make interlocks, only $10.0 \%$ learned soap making. This is in line with the study conducted by Ekegwu et al. ${ }^{14}$ on human empowerment through skills acquisition in Yaba College Lagos State, Nigeria, they reported that, almost half of participants have learned and acquired entrepreneurship skill of computer programming followed by other skills like male saloon, tailoring among others.

Table 3 Skills Acquired by the Respondents

\begin{tabular}{ll}
\hline Skills & *Percentage (\%) \\
\hline Bakery & 21.25 \\
Beads Making & 20 \\
Carpentry & 22.5 \\
Computer & 85 \\
Interlocks & 32.5 \\
Male Saloon & 35 \\
Female Saloon & 12.5 \\
Soap Making & 10 \\
Tailoring & 21.25
\end{tabular}

Source: Field Survey, 2017. *Multiple responses exist

\section{Duration of training and personal business after training}

Result on Table 4 presents the distribution of the respondents according to duration of the training received. The result revealed that almost all (98.8\%) acquired their skills within 1-4 months. This indicated most of the students acquired their skills in short time. This may be because of their younger age that makes them to pick up the skill very fast. The result also shows that only $14 \%$ of the respondents established their own business after acquiring the skills. This may be 
as result of inadequate financial support from the Government or nongovernmental agencies.

Table 4 Duration of Skills Acquired by the Respondents $(n=80)$

\begin{tabular}{lll}
\hline Duration of training (months) & Percentage (\%) & Mean \\
\hline I -4 & 98.8 & 3 \\
8-May & 1.25 & \\
Personal business & & \\
Yes & 17.5 \\
No & 82.5 \\
\hline
\end{tabular}

Source: Field Survey, 2017

\section{Result of the regression analysis}

The result of regression analysis revealed an $\mathrm{R}^{2}$ was 0.8792 (Table 5), which means that $87.92 \%$ of the variation was as result of explainable variables included in the model. The coefficient of age $\left(\mathrm{X}_{1}\right)$, marital status $\left(\mathrm{X}_{2}\right)$ and household size $\left(\mathrm{X}_{3}\right)$ was significant at $1 \%$ level. This implied that as age of the respondents increases, the number of skills acquired by the respondents will increase also. This may because age brings about more experience and reasoning in learning a skill. Increase in the number of people in respondent's house will bring increase in the number of skills the respondent will acquire. This may be because of competition of little resources that may be available the household that will make the respondent to learn more skills as a means of diversification in sources of income.

Table 5 Relationship between Socio-economic Characteristics and Number of Skills Acquired by the Respondents

\begin{tabular}{llll}
\hline Variables & Coefficient & $\begin{array}{l}\text { Standard } \\
\text { error }\end{array}$ & T-value \\
\hline Age $\left(\mathrm{X}_{1}\right)$ & 42.587 & 7.907 & $5.30^{*}$ \\
Marital status $\left(\mathrm{X}_{2}\right)$ & 28.979 & 8.612 & $3.36^{*}$ \\
House hold size $\left(\mathrm{X}_{3}\right)$ & 94.215 & 8.443 & $1 \mathrm{I} .16^{*}$ \\
Education $\left(\mathrm{X}_{4}\right)$ & 2.46 & 8.767 & $0.28 \mathrm{NS}$ \\
Occupation $\left(\mathrm{X}_{5}\right)$ & 3.004 & 2.333 & $1.29 \mathrm{NS}$ \\
Constant & -110.178 & 13.824 & $-7.97^{*}$ \\
$\mathrm{R}^{2}$ & 0.8869 & & \\
Adjusted $\mathrm{R}^{2}$ & 0.8792 & & \\
F-ratio & 116.01 & & \\
\hline
\end{tabular}

Source: Field Survey, 2016. *Significant at I\%. NS, not significant

\section{Constraints to entrepreneurship skill acquisition}

The constraints faced by respondents in acquiring the skills were identified as revealed in Table 6. The most important constraints as revealed by the study were; inadequate number of trainers $(96.3 \%)$ which may lead to few number of respondents that will learn. In adequate of training facilities $(88.8 \%)$, this hinders the respondents from having access to some of skills they need more. Lack of fund to start their own business $(82.5 \%)$ is also a major constraint to the respondents. This also hinders them from being independent after training. This is also a constraint the main aim of the entire programme. This is in cognisance with study conducted by Ajibola et al. ${ }^{15}$ on operations, problems and prospects of youth empowerment programmes in Oyo State, they observed that there was inadequate training facilities to cope with the large number of participating youths, problem of incompetence trainers among the staffs among others.

Table 6 Distribution of respondents according to Problems Associated with Entrepreneurship skills acquisition

\begin{tabular}{ll}
\hline Constraints & *Percentage (\%) \\
\hline In adequate of training facilities & 88.8 \\
$\begin{array}{l}\text { The facilities are not up to } \\
\text { standard (sub-standard) }\end{array}$ & 65 \\
In adequate trainers & 96.3 \\
The trainers are not fully expert & 72.5 \\
Lack of fund to start own business & 82.5 \\
\hline
\end{tabular}

Source: Field Survey, 2016. *Multiple responses exist

\section{Conclusion}

This study analyzed students' participation in entrepreneurship skills acquisition programme in Adamawa State Polytechnic Yola. The findings revealed among others, that majority of the respondents were males, within age of 20-29 years and has their highest level of education as secondary. The result also shows that majority participated in computer and tailoring. The regression analysis result revealed that the variables of age $\left(\mathrm{X}_{1}\right)$, marital status $\left(\mathrm{X}_{2}\right)$ and Household size $\left(\mathrm{X}_{3}\right)$ to be positive and significantly related with the number of skills acquired by the respondents. Participation in entrepreneurship skills acquisition programme was found to have positive impact on the respondents. As those who were found to be engaged, learned various skills and some were gainfully employed through the skills they learned, thus harnessing their youth energy.

\section{Recommendations}

Based on the findings of the research, the following recommendations were made;

I. Adequate and standard facilities should be provided by the concern organization (Government or non-governmental) for proper training of the students.

II. Graduates of entrepreneurship skills acquisition programme should be supported with micro credits to start own business.

III. Adequate and qualified trainers should be employed by the institution.

\section{Acknowledgements}

None.

\section{Conflict of interest}

Authors declare there is no conflict of interest in publishing the article. 


\section{References}

1. Eremie S. Youth; A strong hold for sustainable Agric extension delivery and development" proceeding of $8^{\text {th }}$ annual National conference of Agricultural Extension Society of Nigeria; 2002.

2. UNYA. United Nation Youth Agenda annual report. 2004.

3. NPC. Nigeria Population Commission Census. Federal Government Official Gazette; 2006

4. Kauffman Foundation. Entrepreneurship education. 2009.

5. Madumere-Obike CU, Abraham NM. Functional and entrepreneurial education at secondary education section: A veritable tool for poverty alleviation. In: Babaloa JB, Akpa GO, Editors. Managing education for sustainable development in developing countries. Lagos: National Association of Educational Administration and Planning; 2008. p. $487-495$.

6. Etuk GK, Ekpo IV. Managing education for poverty alleviation and sustainable development in Nigeria. In: Babaloa JB, Akpa GO, Editors. Managing education for Sustainable development in developing countries. Lagos: National Association for Educational Administration sand Planning. 2008. p. 49-60.

7. NBS. National Bureau of Statistics, Youth Unemployment; 2017.

8. NBS. The National Bureau of Statistic annual report. 2013
9. Adebayo AA, Tukur AL. Climate II Rainfall. Adamawa State in Maps Paracletes publishers Yola, Nigeria; 1999. p. 23-26.

10. Fakuade G. Ethnicity and language in Nigeria Adamawa State in Map. 1999

11. Albert CO, Nnodim AU, Cookey AT. Analysis of skill acquisition programme (SAP) on employment opportunities in rural rivers state. Journal of Research on humanities and social science. 2013;3(9):106-108.

12. Ajayi OJ, Yisa ES. Youth empowerment scheme in a demonstration setting: a case study of Niger State Nigeria, proceeding $9^{\text {th }}$ Annual National conference of Agricultural Extension Society of Nigeria March $8^{\text {th }}-11^{\text {th }} .2004$.

13. Pur JT, Shehu I, Sabo E. The Role of Youth Association in Empowering Youths in Agricultural Activities in Adamawa State, Nigeria. Medwell Online Agricultural Journal. 2007;2(5):602-605.

14. Ekegwu EM, Ajiboye YO, Aromolaran AD, et al. Human empowerment through skills acquisition: Issues, Impact, and consequences - A NonParametric View. Journal of poverty, investment and development. 2014;5:15-21.

15. Ajibola A, Salau J, Odunayo P, et al. Operations, problems and prospects of youth empowerment programmes in Oyo state, Nigerian. Journal of Economics and development studies. 2014;2(3):237-238. 